\title{
Cerebellar Toxicity of Phencyclidine
}

\author{
Riitta Näkki, Jari Koistinaho, Frank R. Sharp, and Stephen M. Sagar \\ Department of Neurology, University of California, and Veterans Affairs Medical Center, San Francisco, California \\ 94121
}

Phencyclidine (PCP), dizocilpine maleate (MK801), and other NMDA antagonists are toxic to neurons in the posterior cingulate and retrosplenial cortex. To determine if additional neurons are damaged, the distribution of microglial activation and $70 \mathrm{kDa}$ heat shock protein (HSP70) induction was studied following the administration of PCP and MK801 to rats. PCP (10-50 mg/kg) induced microglial activation and neuronal HSP70 mRNA and protein expression in the posterior cingulate and retrosplenial cortex. In addition, coronal sections of the cerebellar vermis of PCP (50 $\mathrm{mg} / \mathrm{kg}$ ) treated rats contained vertical stripes of activated microglial in the molecular layer. In the sagittal plane, the microglial activation occurred in irregularly shaped patches, suggesting damage to Purkinje cells. In accord with this finding, PCP induced HSP70 protein and mRNA expression in Purkinje cells. Although there were relatively few foci of microglial activation and cells with HSP7O protein induction, HSP70 mRNA was detected in many Purkinje cells located throughout the cerebellar hemispheres as well as the vermis.

MK801, at doses of $5-10 \mathrm{mg} / \mathrm{kg}$, induced microglial activation and neuronal HSP70 mRNA and protein expression in the cingulate and retrosplenial cortex but not in the cerebellum. At the dose of $1 \mathrm{mg} / \mathrm{kg}$ MK801 induced HSP70 but did not consistently activate microglia. These data suggest that microglia are activated by MK801 doses that kill or severely damage neurons, whereas HSP70 is induced in "stressed" neurons at MK801 doses well below those that produce severe neurotoxicity.

These observations suggest that PCP, but not MK801, is toxic to Purkinje cells and raise the question of whether NMDA antagonists or sigma ligands other than PCP are toxic to the cerebellum. Moreover, this study illustrates the usefulness of microglial activation and HSP70 induction as markers of neurotoxicity.

[Key words: Purkinje cell, heat shock genes, microglia, NMDA receptors, NMDA antagon/sts, $\sigma$ receptor]

\footnotetext{
Received Mar. 9, 1994; revised Sept. 14, 1994; accepted Sept. 20, 1994

We thank Drs. Jari Honkaniemi and Linda J. Noble for valuable scientific advice and Karen Baner, Kristen Price, Katy Hicks, John Hall, and Jeremy Nickolenko for expert technical assistance. This work was supported by the Merit Review Program of the Department of Veterans Affairs (S.M.S. and F.R.S.), by the CNS Injury and Edema Research Center (NS14543 to F.R.S. and S.M.S.), by the National Institutes of Health (NS28167 to F.R.S.), and by the Maire Taponen Foundation (R.N.).

Correspondence should be addressed to Stephen M. Sagar, M.D., Neurology Service (127), Veterans Affairs Medical Center, 4150 Clement Street, San Francisco, CA 94121.

Copyright $\mathbb{C} 1995$ Society for Neuroscience $0270-6474 / 95 / 152097-12 \$ 05.00 / 0$
}

Phencyclidine (PCP), dizocilpine maleate (MK801), and other NMDA receptor antagonists have attracted increasing attention because of their therapeutic potential. These drugs have neuroprotective properties in animal studies of focal brain ischemia, where excitotoxicity is proposed to be an important mechanism of neuronal cell death (Dalkara et al., 1990; Martinez-Arizala et al., 1990). Moreover, NMDA antagonists decrease neuronal damage and dysfunction in other pathological conditions, including hypoglycemia (Nellgard and Wieloch, 1992) and prolonged seizures (Church and Lodge, 1990; Faingold et al., 1993).

However, NMDA antagonists are toxic to certain neuronal populations in the brain. Olney et al. (1989) demonstrated that the noncompetitive NMDA antagonists, PCP, MK801, and ketamine, induce morphological damage characterized by cytoplasmic vacuoles in neurons in the posterior cingulate and retrosplenial cortex. Sharp et al. (1991b) and Olney et al. (1991) subsequently showed that these drugs induce the $70 \mathrm{kDa}$ heat shock protein (HSP70) in these damaged neurons and that the HSP70 induction is an excellent light microscopic marker for the injured cells.

The mechanism of toxicity of PCP and MK801 is unknown. The drugs are noncompetitive NMDA receptor antagonists. They bind to a specific sitc (referred to here as the NMDA/PCP receptor) in the NMDA receptor macromolecular complex located inside the ion channel, but do not block glutamate binding to the NMDA receptor (Reynolds and Miller, 1990). MK801 binds with much higher affinity than PCP to the NMDA/PCP receptor (Wong et al., 1986). Binding to the NMDA/PCP receptor is dependent on the presence of glutamate and glycine and it is also voltage dependent (Reynolds and Miller, 1990). The anatomical distribution of PCP binding sites is virtually identical with NMDA receptors in cerebral cortex, whereas in cerebellum the distribution of the PCP binding is quite different from that of NMDA (Maragos et al., 1988; Jarvis et al., 1987).

PCP also has a modest affinity for the $\sigma$-site (also called the $\sigma$-receptor), which is distinct from the NMDA receptor complex (Quirion et al., 1987; Contreras et al., 1988). MK801 has little affinity for the $\sigma$-site (Heroux et al., 1992). $\sigma$-Receptors are thought to mediate the psychotomimetic effects of certain benzomorphan opiates (Su, 1993). It is hypothesized that $\sigma$ or NMDA/PCP receptors play a role in mental illness (Jansen and Faull, 1991; Javitt and Zukin, 1991), as PCP induced psychosis mimics schizophrenia (Domino and Luby, 1981). In addition to binding to NMDA/PCP and $\sigma$-receptors, PCP also affects several other signaling systems. These include muscarinic and nicotinic receptors (Lodge and Johnson, 1990), the transmitters dopamine (Lodge and Johnson, 1990), norepinephrine (Lew, 1989; Lodge and Johnson, 1990; Massarimi and Duckles, 1991), ACh (Palma and Wang, 1991; Lodge and Johnson, 1990), and GABA 

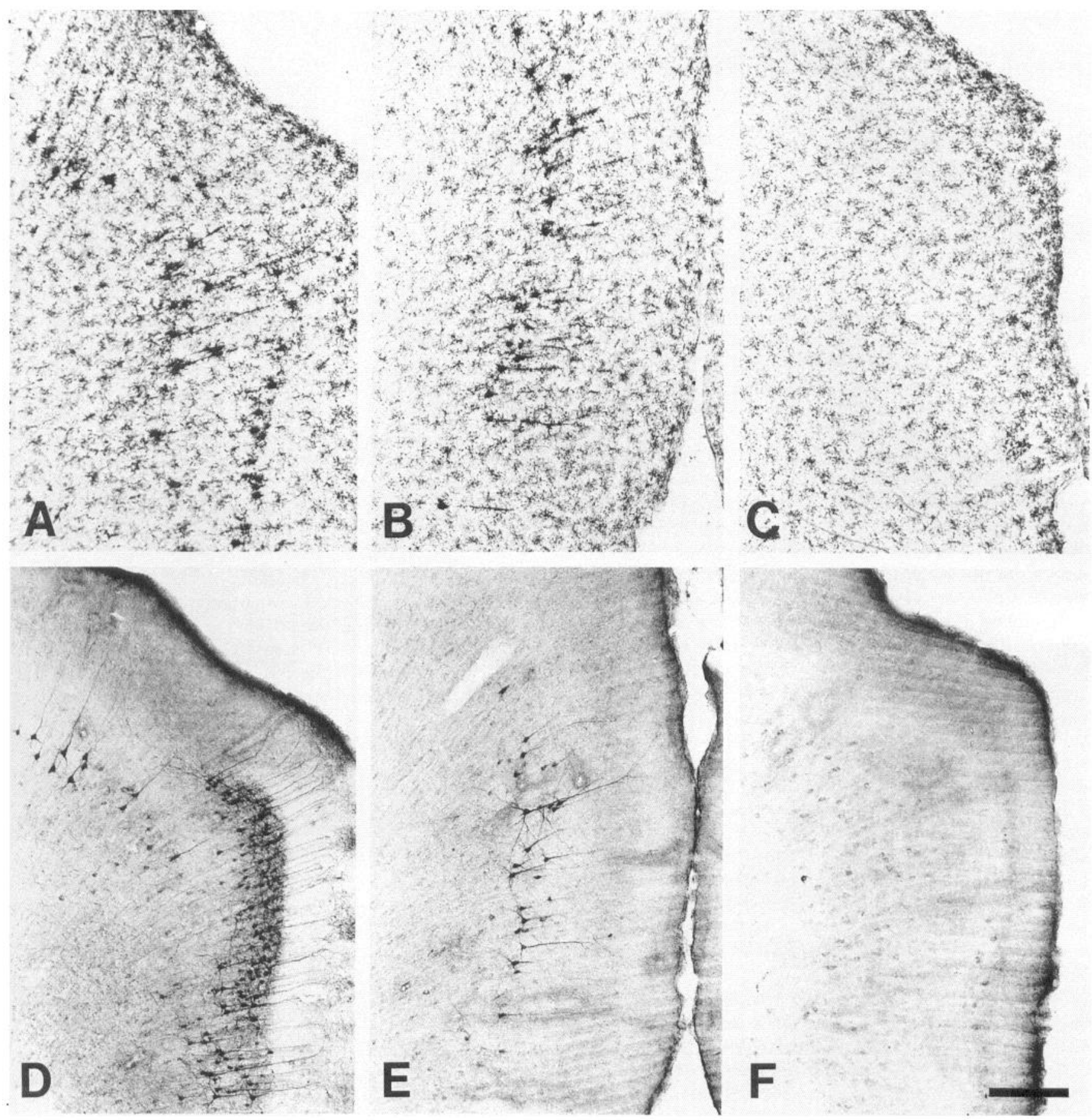

Figure 1. PCP $(50 \mathrm{mg} / \mathrm{kg}$ i.p.) activates microglia $(A, B)$ and induces $\operatorname{HSP} 70(D, E)$ in the posterior cingulate $(A, D)$ and retrosplenial $(B, E)$ cortex $3 \mathrm{~d}$ after injection. There is no microglial activation or HSP70 induction in saline treated controls $(C, F)$. Monoclonal antibodies against C3-complement receptor (OX-42) and heat shock 70 protein (HSP70) were used for microglial and HSP70 staining, respectively. Scale bar, 200 $\mu \mathrm{m}$.

(Seiler and Grauffel, 1992; Sharp et al., 1994); at least one amine transporter (Rothman et al., 1990, 1992; Akunne et al., 1991, 1992); and a $\mathrm{K}^{+}$channel (Lodge and Johṅson, 1990).

The purpose of this study was to further examine PCP and MK801 neurotoxicity in the rat brain. Because of the therapeutic potential of NMDA antagonists, it is important to determine the localization, pharmacology, and possible mechanisms of their neurotoxic effects. In addition, understanding the neurotoxicity of these compounds, particularly PCP, could further our under- standing of the neurobiological bases of schizophrenia and related mental illnesses.

\section{Materials and Methods}

\section{Tissue preparation}

Immunocytochemistry. Adult male Sprague-Dawley rats (180-280 gm) received a single intraperitoneal injection of PCP $(n=40)$ or MK801 $(n=12)$. The PCP doses were $5(n=2), 10(n=5), 25(n=3)$, and $50(n=30) \mathrm{mg} / \mathrm{kg}$ and the MK801 doses were $1(n=4), 5(n=4)$, and $10 \mathrm{mg} / \mathrm{kg}(n=4)$. Control animals received an equal volume of 

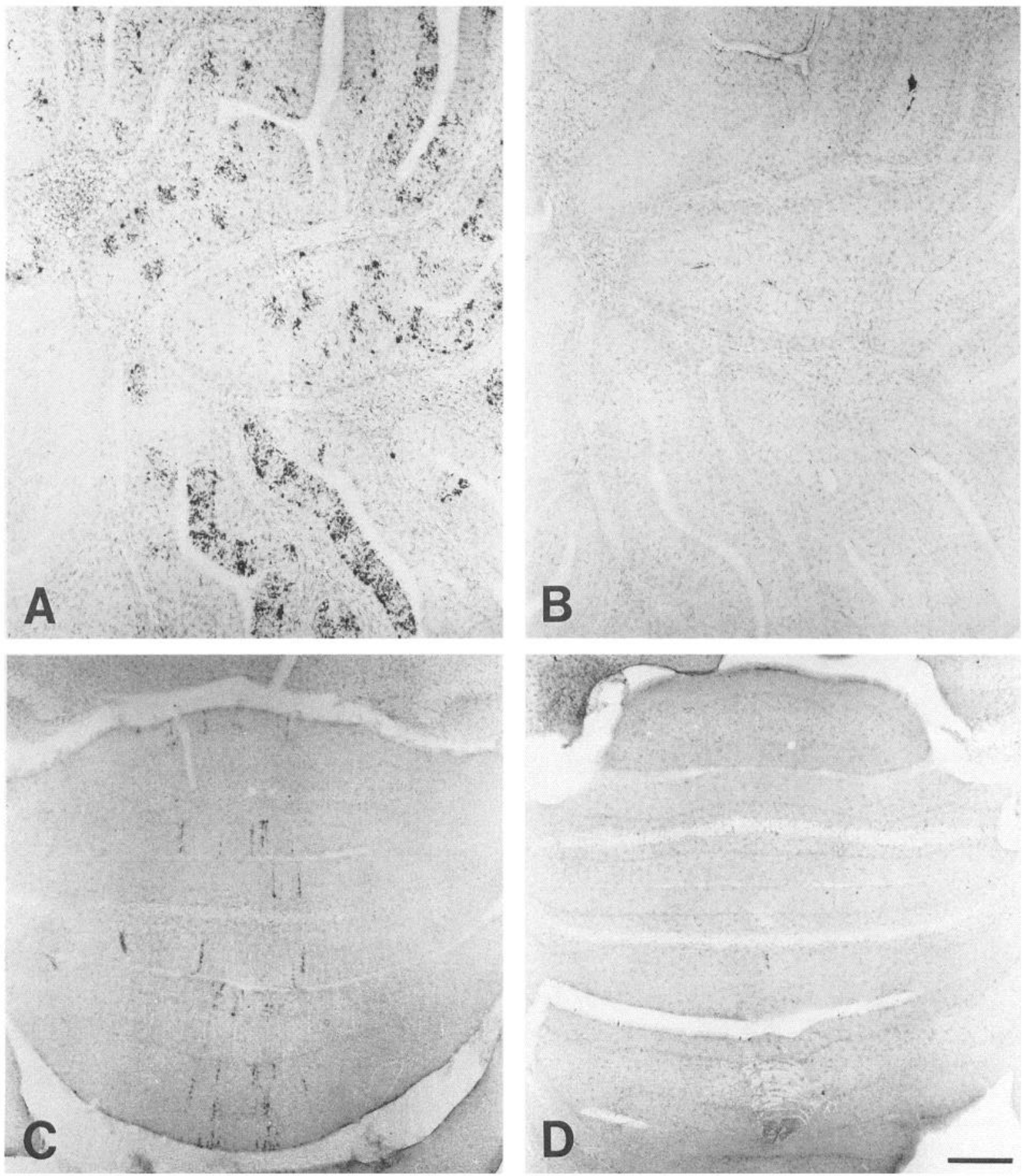

Figure 2. Microglial activation (OX-42) in cerebellar sagittal $(A)$ and coronal $(C)$ sections $2 \mathrm{~d}$ after injection of PCP (50 mg/kg i.p.). Saline treated controls showed no evidence of microglial activation $(B, D)$. Scale bar, $500 \mu \mathrm{m}$.

$0.9 \%$ saline $(n=12)$. After $1-30 \mathrm{~d}$ survivals, animals were anesthetized with sodium pentobarbital $(125 \mathrm{mg} / \mathrm{kg})$ and perfused through the ascending aorta with saline followed by $4 \%$ paraformaldehyde in $0.1 \mathrm{M}$, $\mathrm{pH} 7.4$ sodium phosphate buffer (PB). The brains were postfixed in the same fixative for $2-4 \mathrm{hr}$ at $4^{\circ} \mathrm{C}$. Fifty micrometer thick vibratome sections were processed for immunocytochemistry.

In situ hybridization. Adult rats injected intraperitoneally with PCP $(50 \mathrm{mg} / \mathrm{kg})(n=2)$, MK801 $(10 \mathrm{mg} / \mathrm{kg})(n=1)$, or $0.9 \%$ saline $(n=$ 2 ) were allowed to survive $6 \mathrm{hr}$. They were narcotized with carbon dioxide and decapitated. Brains were removed, blocked, and frozen in 2 -methylbutane at $-30^{\circ} \mathrm{C}$. Twenty micrometer thick sections were cut on a cryostat and thaw mounted onto Probe-On-Slides (Fischer Bio- tech). Sections were air dried and kept frozen until used for in situ hybridization.

\section{Immunocytochemistry}

The monoclonal antibody OX-42 (Serotec, Oxford, England; 1:5000) against the complement $\mathrm{C} 3$ receptor was used to detect activated microglia. Additionally, the monoclonal antibodies OX-6 (Serotec, 1:1000) against the major histocompatibility complex Class II antigen, and ED-1 (Serotec, 1:1000) against a cytoplasmic monocyte/macrophage antigen and biotinylated isolectin B4 (IB4) (Sigma Chemical Co., St. Louis, $\mathrm{MO} ; 4 \mu \mathrm{g} / \mathrm{ml}$ ) from Griffonia simplicifolia were used to detect microg- 

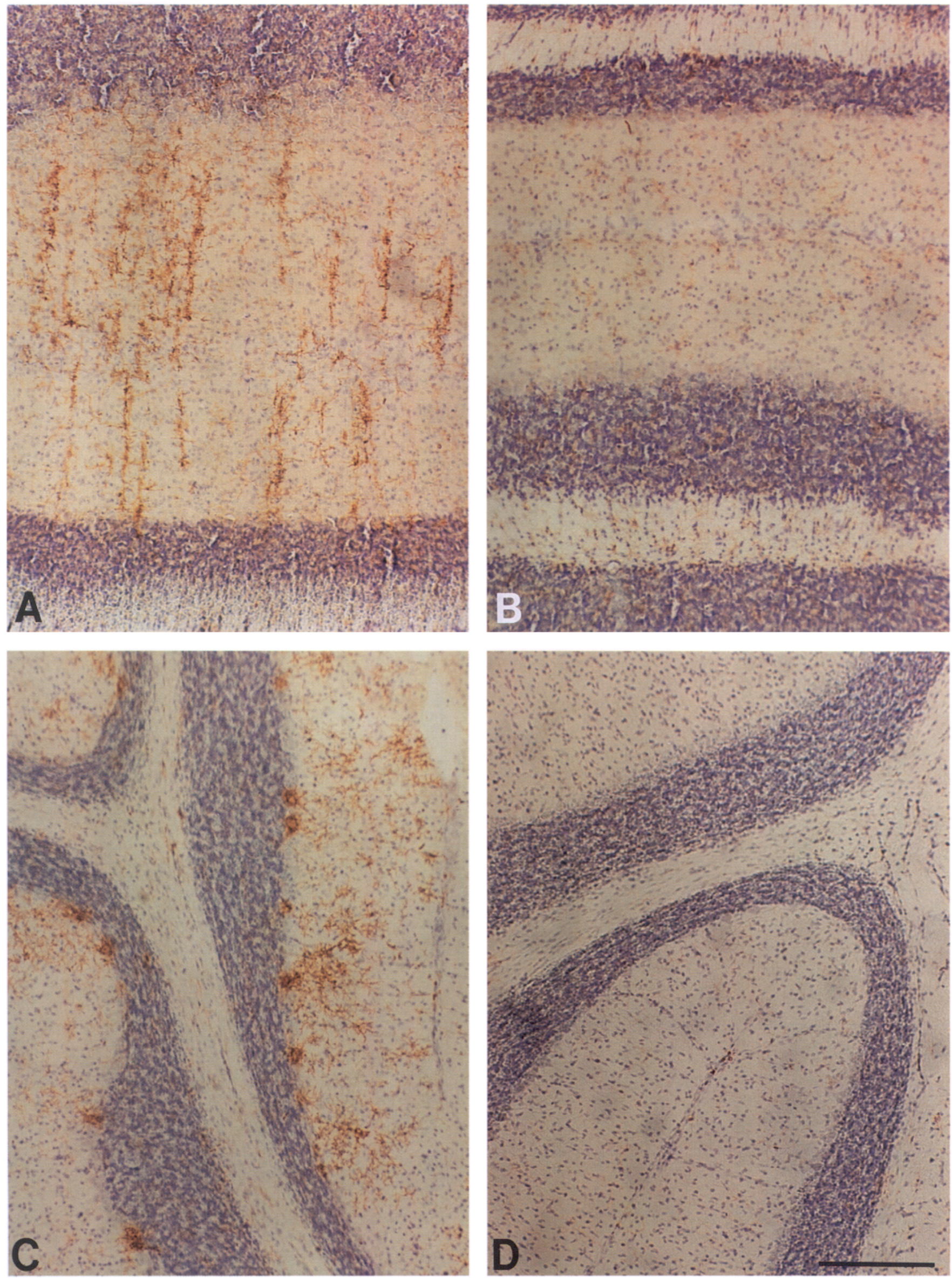

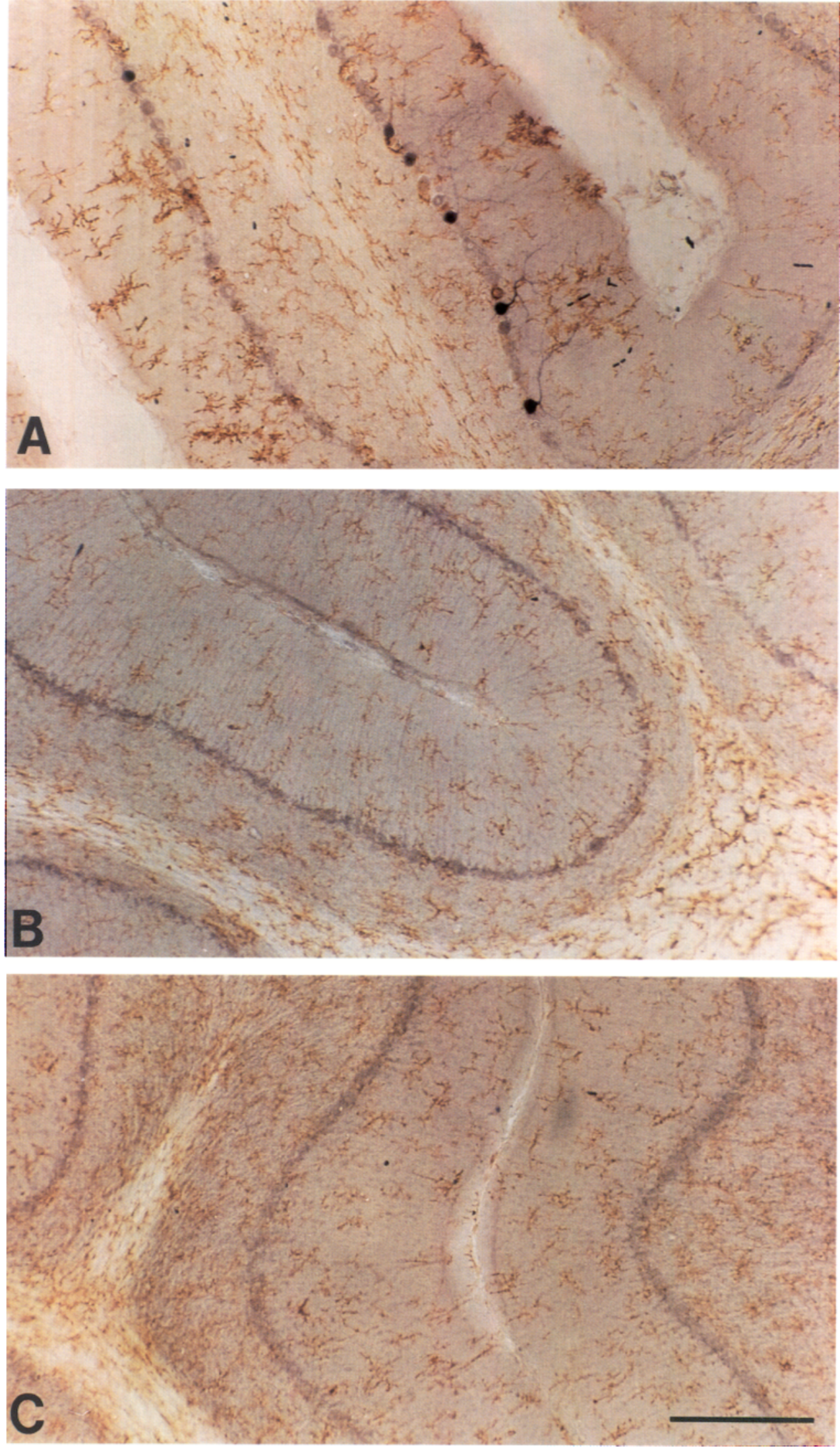

Figure 4. Cerebellar sagittal sections of rats injected with $(A) \mathrm{PCP}(50 \mathrm{mg} / \mathrm{kg}$ i.p.), (B) MK801 (10 mg/kg i.p.), and (C) saline $24 \mathrm{hr}$ previously. Sections are immunostained for HSP70 (dark bluelblack) and microglia (OX-42, brown). PCP treated animals showed activated microglia in the molecular layer and HSP70 immunoreactivity in Purkinje cells $(A)$. MK801 $(B)$ and saline $(C)$ treated animals showed resting microglia and no HSP70 immunostaining. Scale bar, $200 \mu \mathrm{m}$.

$\leftarrow$

Figure 3. Microglial activation (OX-42) in cerebellar coronal $(A)$ and sagittal $(C)$ sections $4 \mathrm{~d}$ after injection of PCP (50 mg/kg i.p.). Saline treated controls showed no evidence of microglial activation $(B, D)$. Sections are counterstained with cresyl violet. Scale bar, $200 \mu \mathrm{m}$. 
lia in selected sections. The monoclonal antibody to HSP70 from Amersham U.K. $(1: 4000)$ was used to stain for the inducible heat shock protein 70 (HSP70). This antibody (Welch and Suhan, 1986) produces one major band on Western blots of ischemic gerbil brain (Vass et al., 1988), one band on Western blots of heated rat brain and retina (Barbe et al., 1988), and one band on Western blots of heat shocked rat astrocyte cultures (Swanson et al., personal communication). The antibody recognizes the product of the rat HSP70 gene that we have cloned and expressed in fibroblasts (Longo et al., 1993).

The primary antibody or lectin was diluted in $0.1 \mathrm{M}$ sodium phosphate buffer, $\mathrm{pH} 7.4$, containing $0.1 \%$ bovine serum albumin, $0.2 \%$ Triton X-100, and $2 \%$ horse serum. The tissue sections were incubated in the primary antibody for $36-72 \mathrm{hr}$ at $4^{\circ} \mathrm{C}$ and the bound antibody was visualized with the avidin-biotin-peroxidase (ABC) method (Vectastain Kit, Vector Labs., Burlingame, CA) using 3,3'-diaminobenzidine (DAB) as the peroxidase substrate. For HSP70 staining biotinylated sheep anti-mouse Ig (Amersham) was used as the secondary antibody. Controls for the immunostaining, which included omission of the primary antibody or lectin, demonstrated no microglial or HSP70 staining. Some sections were counterstained with cresyl violet, hematoxylin and eosin, or neutral red.

\section{In situ hybridization histochemistry}

A 30-mer anti-sense oligonucleotide probe complimentary to the sequence coding for amino acids 122-129 of the inducible HSP70 gene was used (5'-CGATCTCCTTCATCTTGGTCAGCACCATGG-3'). This oligonucleotide distinguishes between the inducible HSP70 (Hunt and Morimoto, 1985) and constitutive HSC73 genes on Northern blots of rat brain (Miller et al., 1991) and produces very little signal on in situ hybridization of normal rat brain (Sharp et al., 1994). The probe was $3^{\prime}$ end labeled with ${ }^{35} \mathrm{~S}$-ATP using terminal deoxynucleotidyl transferase (New England Nuclear) and purified over Nuctrap Push Columns (Stratagene). Two hundred microliters of the hybridization solution containing $10 \times 10^{6} \mathrm{cpm} / \mathrm{ml}$ probe, $40 \mu \mathrm{l}$ of $5 \mathrm{M}$ dithiothreitol, $50 \mu \mathrm{l}$ of salmon sperm DNA $(10 \mathrm{mg} / \mathrm{ml})$, and $900 \mu \mathrm{l}$ of hybridization cocktail $(50 \mathrm{ml}$ of formamide, $20 \mathrm{ml}$ of $20 \times \mathrm{SSC}, 2 \mathrm{ml}$ of $50 \times$ Denhardt's reagent,

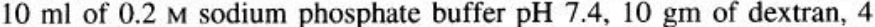
$\mathrm{ml}$ of $25 \%$ sarcosyl) was placed between two slides which were sandwiched together. After $18 \mathrm{hr}$ at $37^{\circ} \mathrm{C}$, sections were washed $2 \times 5 \mathrm{sec}$ in $1 \times \mathrm{SSC}$ at $55^{\circ} \mathrm{C}, 4 \times 15 \mathrm{~min}$ in $1 \times \mathrm{SSC}$ at $55^{\circ} \mathrm{C}, 60 \mathrm{~min}$ in $1 \times$ SSC at room temperature, $2 \times 5 \mathrm{~min}$ in deionized water at room temperature, $30 \mathrm{sec}$ in $60 \%$ ethanol and $30 \mathrm{sec}$ in $95 \%$ ethanol at room temperature. The sections were air dried and autoradiographed on Kodak SB5 x-ray film. Slides were dipped in Kodak NTB2 nuclear emulsion and exposed for 30-60 d. After photographic developing, the sections were counterstained with neutral red. Control sections treated with RNase and hybridized with the antisense probe and control sections hybridized with a sense oligonucleotide probe showed no evidence of specific hybridization.

\section{Results}

\section{Behavioral observations}

Behavioral responses occurred within 1-2 min of PCP and 2-5 min of MK801 administration. At lower doses (PCP 5-25 $\mathrm{mg} / \mathrm{kg}, \mathrm{MK} 801 \mathrm{1-2} \mathrm{mg} / \mathrm{kg}$ ) the rats exhibited characteristic hyperactivity, including head waving, circling, and rearing movements together with tremor, truncal ataxia, decreased muscle tone, and extended curved tail position. At higher doses (PCP $50 \mathrm{mg} / \mathrm{kg}$, MK801 5-10 mg/kg) they initially lay in one place with tremulous extremities and then gradually, over $2-4 \mathrm{hr}$, exhibited increased motor activity similar to that of the low dose animals. The abnormal behavior persisted for 2-12 hr and was gradually followed by normal spontaneous activity. The duration of the symptoms varied with different doses of the drugs from 2-3 hr with low doses of PCP to 7-8 hr with high doses of PCP and 8-12 hr with high doses of MK801. At $24 \mathrm{hr}$, the drug treated rats appeared behaviorally similar to the saline treated controls. There was little difference between the behavior of PCP and MK801 treated rats.

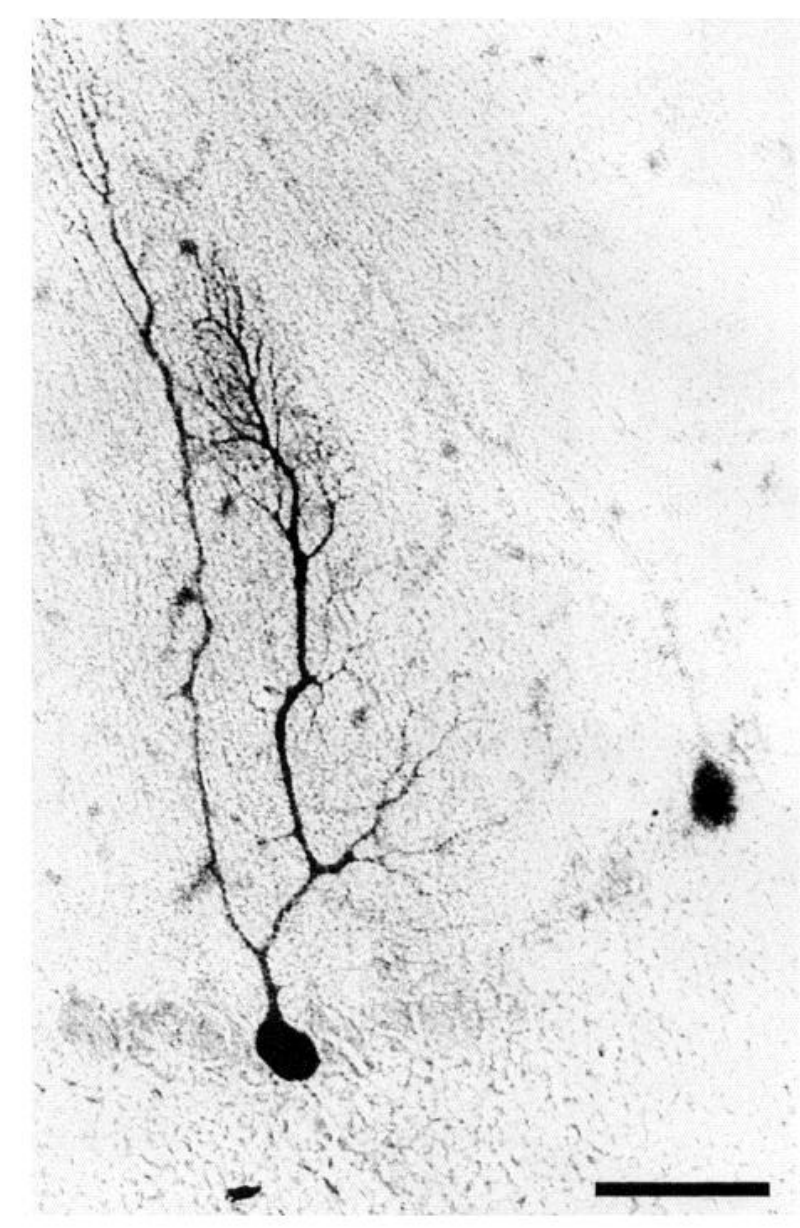

Figure 5. HSP70 immunoreactive Purkinje cell in a sagittal section of cerebellum of a rat injected with PCP $(50 \mathrm{mg} / \mathrm{kg}$ i.p.) $24 \mathrm{hr}$ previously. Scale bar, $50 \mu \mathrm{m}$.

\section{PCP-and MK801-induced microglial activation}

Activated microglia were stained with all of the markers used. Though OX-42 stains both activated and resting microglia, the staining of the activated microglia was more intense. OX-6, ED-1, and the lectin IB4 stain the activated microglia intensely but few or none of the resting microglia. Because OX-42 produced the most robust and consistent immunostaining, it was used routinely in these experiments. The activated microglia detected with OX-42 were also detected using OX-6, ED-1, and IB 4 in each experiment, confirming that identical patterns of microglial activation were obtained with each of the markers.

PCP produced microglial activation in the posterior cingulate and retrosplenial cortex at doses of $10-50 \mathrm{mg} / \mathrm{kg}$ (Fig. 1A,B) When studied 1-10 d after injection, the reaction was consistently detected in the rats injected with doses of $25(n=3)$ and $50 \mathrm{mg} / \mathrm{kg}(n=24) \mathrm{PCP}$ but only in two of the five rats receiving the $10 \mathrm{mg} / \mathrm{kg}$ dose. In the retrosplenial and most posterior cingulate cortex microglial activation was detected in cortical layers 3 and 5 (Fig. 1A), whereas in more anterior parts of posterior cingulate only one layer of activated microglia could be visualized (Fig. $1 B$ ). At least some of the PCP treated animals also had activated microglia in the pyriform cortex and neocortex, but detailed analyses of these areas were not carried out for the present study. 
In addition to these areas, microglial activation was consistently observed in the cerebellum (Figs. $2 A, C ; 3 A, C$ ) $1-10 \mathrm{~d}$ following the administration of $50 \mathrm{mg} / \mathrm{kg}$ of PCP $(n=24)$. Coronal sections of PCP $(50 \mathrm{mg} / \mathrm{kg})$ treated rats contained vertical stripes of activated microglia in the molecular layer of the cerebellum (Figs. $2 A, 3 A$ ). Almost all of the stripes were in the vermis (Fig. $2 C$ ). In sagittal sections the activated microglia appeared in irregularly shaped clusters in the molecular layer following the pattern of Purkinje cell dendrites, the most intense staining being around Purkinje cell bodies (Fig. $3 C$ ). Although activation of microglia was seen in the cerebellums of all animals receiving $50 \mathrm{mg} / \mathrm{kg} \mathrm{PCP}$, the number of patches of activated microglia varied between individual rats. The $10(n=5)$ and $25 \mathrm{mg} / \mathrm{kg}(n=3)$ doses of PCP produced activated microglia in the cingulate and retrosplenial cortex, but never in the cerebellum. The $5 \mathrm{mg} / \mathrm{kg}$ dose of PCP $(n=2)$ produced patterns of microglial staining that were indistinguishable from the saline treated controls.

Microglial activation in posterior cingulate cortex occurred as early as $1 \mathrm{~d}$ after PCP $(50 \mathrm{mg} / \mathrm{kg})$ treatment and reached its peak between 3 and $7 \mathrm{~d}$. At $30 \mathrm{~d}$ the microglia appeared to have returned to the resting state, since the patterns of OX-42 staining at $30 \mathrm{~d}$ were similar to the patterns of OX-42 stained microglia in the saline injected control animals. The time course of microglial activation after PCP injection was similar in the cerebral cortex and in the cerebellum.

MK801, like PCP, induced a dose dependent microglial response in the cingulate, retrosplenial, and pyriform cortex when examined 1-5 d after intraperitoneal injection. Microglial activation was seen in posterior cingulate and retrosplenial cortex in one of the four animals receiving $1 \mathrm{mg} / \mathrm{kg}$ dose of MK801 and in all of the animals receiving $5(n=4)$ and $10 \mathrm{mg} / \mathrm{kg}(n$ =4) MK801. The number of activated microglial cells increased at higher doses of MK801. However, MK801 did not induce cerebellar microglial activation at any of the doses used (Fig. $4 B)$. The saline injected controls $(n=12)$ (Figs. $1 C ; 2 B, D ; 3 B, D)$ exhibited only rare, scattered activated microglial cells with no consistent regional localization.

\section{PCP- and MK801-induced HSP70 protein expression}

HSP70 immunostaining was detected $12 \mathrm{hr}, 1 \mathrm{~d}, 3 \mathrm{~d}$, and $7 \mathrm{~d}$ after PCP $(10-50 \mathrm{mg} / \mathrm{kg})(n=20)$ or MK801 $(1-10 \mathrm{mg} / \mathrm{kg})(n$ $=12$ ) treatment. Longer time points were not studied though MK801 has been shown to induce HSP70 protein for up to 2 weeks (Sharp et al., 1991b). HSP70 immunostaining was induced in pyramidal neurons in the same areas as the microglial activation in the cingulate, retrosplenial, pyriform, and neocortex in PCP (Fig. 1D,E) and MK801 treated animals. In PCP (50 $\mathrm{mg} / \mathrm{kg})(n=7)$ treated animals HSP70 immunoreactive Purkinje cells were consistently detected in cerebellum (Figs. 4A, 5), whereas HSP70 immunoreactive Purkinje cells were never detected in cerebellum of MK801 $(n=12)$ (Fig. $4 B$ ) or saline ( $n$ =12) (Fig. $4 C$ ) treated animals.

The HSP70 immunoreactive Purkinje cells in PCP treated rats did not consistently co-localize with the activated microglia, even though both of the markers were concentrated in the cerebellar vermis (Figs. 4A, 6A-C). Some Purkinje cells stained for HSP70 without evidence of microglial activation (Fig. 6A), and other Purkinje cells were HSP70 negative but were surrounded by activated microglia (Fig. $6 \mathrm{C}$ ). There were also instances of HSP70 immunoreactive Purkinje cells that had activated microglia surrounding their perikarya and dendrites (Fig. 6B). No additional HSP70 positive cells, aside from Purkinje cells, were detected in cerebellum. No HSP70 positive staining was detected in any cells of the forebrain or cerebellum of the saline injected control animals.

\section{PCP-and MK801-induced HSP70 MRNA expression}

In situ hybridization histochemistry of brain sections from PCP $(50 \mathrm{mg} / \mathrm{kg})(n=2)$ treated rats demonstrated the expression of HSP70 mRNA in Purkinje cells throughout the cerebellum. Cellular resolution autoradiography confirmed that the silver grains were located mainly over Purkinje cell bodies (Fig. 7A,B). The HSP70 mRNA expression varied between individual Purkinje cells (Fig. 7B). The number of HSP70 mRNA positive Purkinje cells was many times larger than the number of activated microglial stripes or HSP70 immunostained Purkinje cells in the cerebellum of rats treated with $50 \mathrm{mg} / \mathrm{kg}$ of PCP. HSP70 mRNA was detected not only in vermal Purkinje cells but also in Purkinje cells located throughout the cerebellar hemispheres. PCP $(50 \mathrm{mg} / \mathrm{kg}$ ) also induced HSP70 mRNA in pyramidal neurons located in layers 3 and 5 of posterior cingulate and retrosplenial cortex as previously reported (Sharp et al,, 1992).

MK801 $(10 \mathrm{mg} / \mathrm{kg})(n=1)$ also induced HSP70 mRNA in pyramidal neurons in layers 3 and 5 of the cingulate and retrosplenial cortex. There were no HSP70 mRNA positive neurons in the cerebellum of rats injected with MK801 (Fig. 7C). The saline injected animals $(n=2)$ did not exhibit specific staining for HSP70 mRNA in the cerebrum or cerebellum (Fig. 7D).

\section{Discussion}

Previous studies have shown that the NMDA receptor antagonists PCP, MK801, and ketamine produce vacuoles in the cytoplasm of pyramidal neurons in layers 3 and 5 of posterior cingulate and retrosplenial cortex (Olney et al., 1989, 1991; Allen and Iversen, 1990; Sharp et al., 1991b; Fix et al., 1993). Subsequently, the HSP70 heat shock protein was found to be induced in these vacuolated neurons (Olney et al., 1991; Sharp et al., 1991b, 1992). Moreover, MK801 has been demonstrated to cause neuronal death in the retrosplenial cortex (Fix et al., 1993). The present study shows that PCP and MK801 activate microglia around pyramidal neurons in the same areas. Moreover, high doses of PCP $(50 \mathrm{mg} / \mathrm{kg})$, but not MK801, activate microglia surrounding Purkinje cells and induce HSP70 mRNA and HSP70 protein in Purkinje cells. These results strongly suggest that PCP, but not MK801, injures Purkinje cells in rodent cerebellum.

Microglial activation has been well characterized in numerous studies as a marker of neural injury (Thomas, 1992). Normal brain microglia, the resident macrophage population in the CNS, have a "resting," ramified morphology. They express some, but not all macrophage markers, including complement $\mathrm{C} 3$ receptors (Perry and Gordon, 1988) and carbohydrates that bind to certain lectins (Streit and Kreutzberg, 1987). However, most of their macrophage properties are downregulated. Following brain injury microglia proliferate, collect at the site of injury, undergo morphological alteration, and express or upregulate macrophage associated antigens (Thomas, 1992). This results in more intense staining with antibodies to the complement receptor and lectins and in the expression of macrophage markers such as EDI and major histocompatibility complex (MHC) Class II antigens. Activated microglia can become phagocytic and participate in removing dead tissue (Thomas, 1992). Microglial activation is a sensitive and rclativcly nonspccific indicator of cell damage. It 

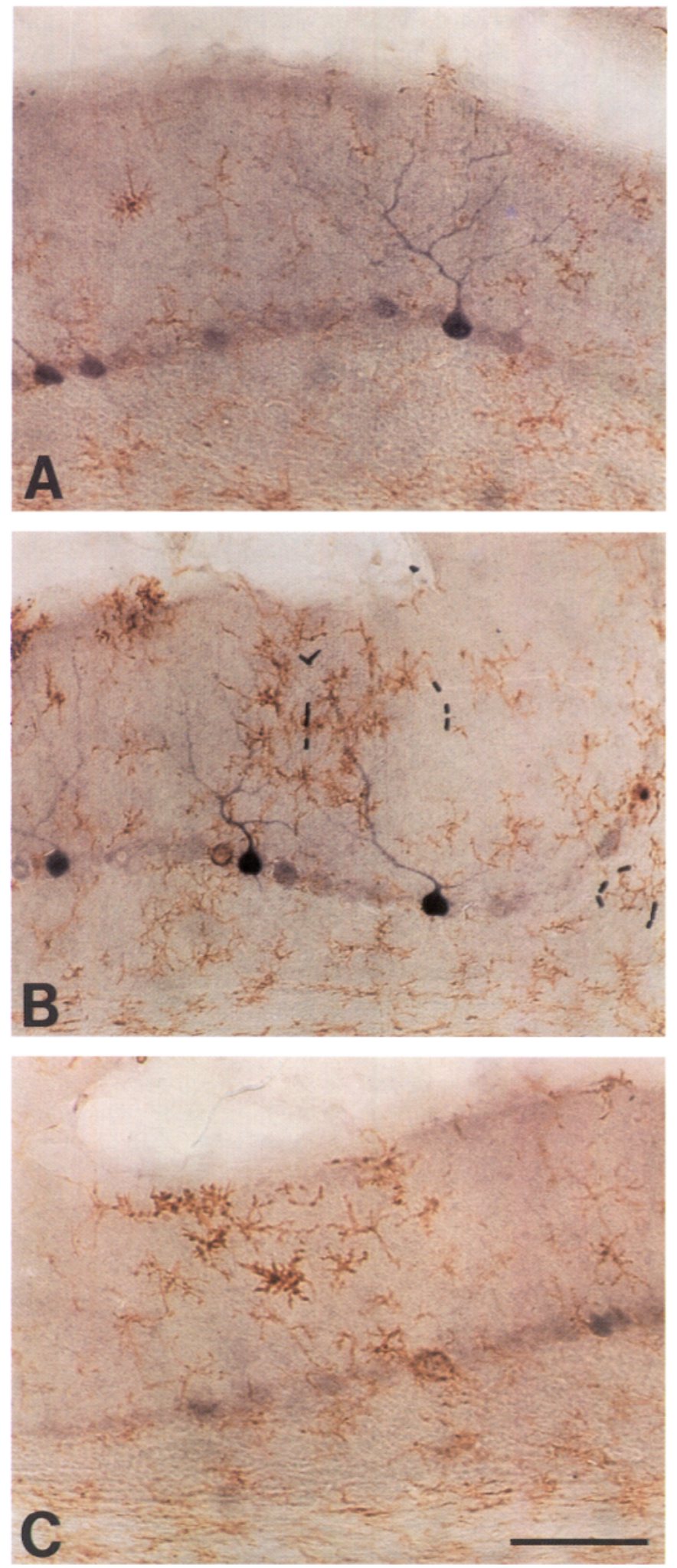

Figure 6. HSP70 positive immunostaining (dark bluelblack) and OX42 microglial immunostaining (brown) in sagittal sections of a rat injected with PCP (50 mg/kg i.p.) $24 \mathrm{hr}$ previously. Some of the HSP70 positive Purkinje cells had activated microglial surrounding them $(B)$ and some did not $(A)$. Activated microglia were also detected around Purkinje cells that were not immunoreactive for HSP70 $(C)$. Scale bar, $100 \mu \mathrm{m}$. occurs in a variety of injuries, including physical, chemical, ischemic, and infectious insults (Streit et al., 1988; Thomas, 1992). However, the actual molecular mechanism of microglial activation in neuronal injury remains to be defined. Myelin and axonal degeneration have been suggested to induce microglial activation (Finsen et al., 1993). Moreover, cytokines secreted by astrocytes are mitogenic for microglia (Frei et al., 1986). On the other hand, interleukin-1 (IL-1), which is secreted by microglia, is mitogenic to astrocytes (Giulian and Lachman, 1985; Giulian et al., 1986), indicating a reciprocal interaction between microglia and astrocytes in CNS damage and healing. Despite this extensive literature, it remains unknown if microglial activation after neuronal injury requires the death of neurons or can result from sublethal neuronal injury.

HSP70 induction as a marker of neural injury differs from the microglial reaction. HSP70 induction likely indicates cell damage or "stress" rather than cell death (Gonzalez et al., 1989, 1991; Simon et al., 1991). HSP70 synthesis is induced by various stresses, including heat shock, ischemia, prolonged seizures, and toxins (Vass et al., 1988, 1989; Gonzalez et al., 1989, 1991; Brown, 1990; Sharp et al., 1991a). Most of these conditions are thought to denature intracellular proteins and activate heat shock factors that bind to the heat shock elements in the promoters of heat shock genes to initiate heat shock gene transcription (Anathan et al., 1986). HSP70 protein family members have a protective function. They prevent partially denatured proteins from becoming irreversibly denatured (Pelham, 1986), facilitate protein import into cell organelles (Deshaies et al., 1988), and interact transiently with newly synthesized proteins to ensure proper folding (Beckmann et al., 1990). The protective role of HSP70 is supported by the observation that HSP70 protein increases cell survival after heat shock (Johnston and Kucey, 1988; Riabowol et al., 1988) and that HSP70 induction prior to a stressor decreases cell damage (Walsh et al., 1987, 1989; Barbe et al., 1988; Tytell et al., 1989). The preponderance of evidence indicates that HSP70 is produced in cells that will survive the stress (Vass et al., 1988; Sharp et al., 1991a), although HSP70 protein can be induced in cells that are destined to die in global ischemia (Simon et al., 1991). However, following focal ischemia severe enough to produce cell death, the expression of HSP70 mRNA and protein is blocked in most neurons and glia that go on to die from the insult (Li et al., 1992; Kinouchi et al., 1993).

High doses of MK801 (5-10 mg/kg) lead to death of scattered pyramidal neurons in the posterior cingulate and retrosplenial cortex of adult rats (Allen and Iversen, 1990; Fix et al., 1993). These are the same doses of MK801 required to produce microglial activation in posterior cingulate (the present study; Fix et al., 1993). Moreover, Fix et al. (1993) demonstrated that reactive microglial cells contact necrotic neurons after high doses of MK801. MK801 induces HSP70 in posterior cingulate and retrosplenial pyramidal neurons at doses as low as $0.2 \mathrm{mg} / \mathrm{kg}$ (Sharp et al., 1991b), doses well below those that lead to cell death. This suggests, but does not prove, that MK801-induced microglial activation reflects neural death while HSP70 expression indicates primarily a sublethal neural injury.

With PCP, the present study did not reveal a dissociation of the doses of drug required to produce HSP70 expression and microglial activation. In the forebrain, both microglial activation and HSP70 expression occurs after PCP over a range of doses from 10 to $50 \mathrm{mg} / \mathrm{kg}$. At $10 \mathrm{mg} / \mathrm{kg}$, PCP produces only occasional activated microglial cells in the forebrain, whereas doses 

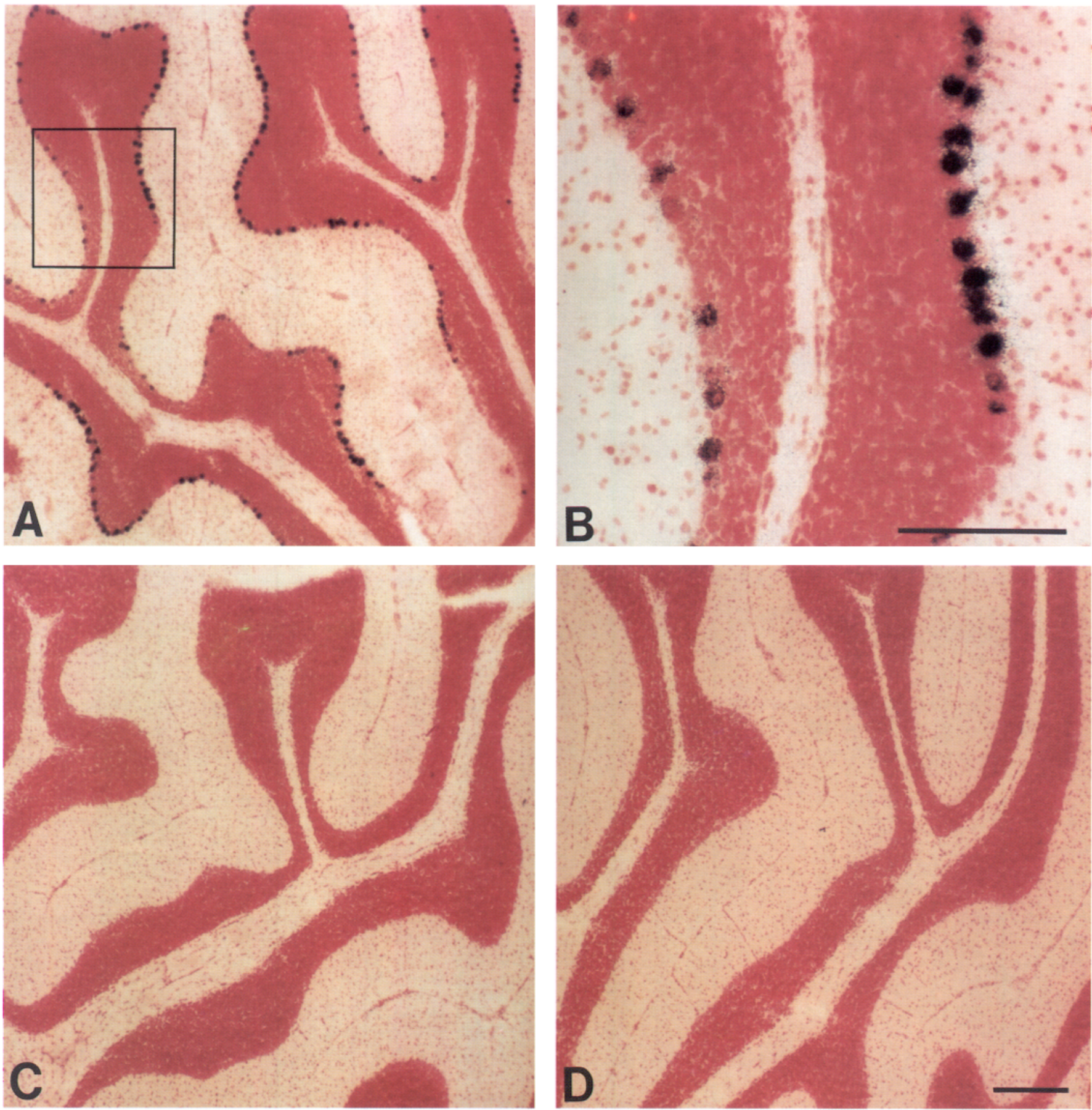

Figure 7. HSP70 mRNA in the Purkinje cells of a rat injected with PCP (50 mg/kg i.p.) $6 \mathrm{hr}$ previously $(A, B)$. Rats injected with MK801 (10 $\mathrm{mg} / \mathrm{kg}$ i.p.) $(C)$, and saline $(D)$ did not exhibit any specific hybridization signal for HSP70 mRNA in the cerebellum. Sections are counterstained with neutral red. Scale bars, $200 \mu \mathrm{m}$.

of 25 and $50 \mathrm{mg} / \mathrm{kg}$ consistently produce substantial numbers of activated microglia (Fig. $1 A, B$ ). In the forebrain, the vast majority of activated microglia and neurons expressing HSP70 are detected in posterior cingulate and retrosplenial cortex. In the cerebellum, PCP, $50 \mathrm{mg} / \mathrm{kg}$, but not lower doses, consistently produced patches of activated microglia surrounding cerebellar Purkinje cell bodies and in the molecular layer. Moreover, HSP70 mRNA and protein were expressed in Purkinje cells. As in the forebrain, it remains to be determined if the activated microglia mark dying or damaged Purkinje cells.
The distribution of microglial activation matches the pattern of HSP70 induction in the posterior cingulate and retrosplenial cortex following the administration of both PCP and MK801. However, the distribution of microglial activation overlaps, but does not match, the pattern of HSP70 induction in cerebellar Purkinje cells after high dose PCP. This discrepancy could reflect either different degrees or different types of neuronal injury. It is therefore possible that HSP70 positive Purkinje cells without surrounding activated microglia are less severely injured than HSP70 positive Purkinje cells which are surrounded by activated 
microglia. The Purkinje cells that are HSP70 negative but are surrounded by activated microglia may have sustained an injury so severe that they are unable to synthesize the HSP70 protein. Alternatively, it is possible that PCP damages Purkinje cells through two separate mechanisms, one marked by HSP70 induction and the other by microglial activation. If this explanation is true, our observations suggest that only a minority of Purkinje cells are vulnerable to both mechanisms.

The present observations could be confounded by different time courses in the expression of the markers. The time required for maximal HSP70 protein expression is shorter (12-48 hr) (Sharp et al., 1991b) than the time required for microglial activation (24-96 hr) (Brierley and Brown, 1982; Streit and Kreutzberg, 1987). When examining the rats surviving $24 \mathrm{hr}$ after PCP treatment for HSP70, it is likely that much of the microglial activation had not yet occurred. However, when examined at 3 $\mathrm{d}$, the distribution of HSP70 induction still failed to match the distribution of microglial activation in cerebellum, supporting the idea that there are different degrees or mechanisms of injury in different Purkinje cell neurons.

The possibility that damaged cells other than Purkinje cells contribute to the microglial activation in the molecular layer appears unlikely. The most intense microglial activation occurs surrounding Purkinje cell bodies, and the patches of activated microglia in the molecular layer are confined to the plane of Purkinje cell dendrites. Moreover, HSP70 mRNA and protein are expressed exclusively in Purkinje cells in the cerebellum, suggesting selective damage to these cells.

The anatomical sitc of prodominant cerebellar microglial activation and HSP70 protein induction is the cerebellar vermis. Though the highest density of HSP70 mRNA expression is in Purkinje cells located in the vermis, HSP70 mRNA is also induced in Purkinje cells scattered throughout the intermediate zone and in the cerebellar hemispheres. In the vermis HSP70 mRNA is detected in a larger number of Purkinje cells than HSP70 protein or microglial activation. The relative paucity of HSP70 immunostained Purkinje cells in comparison with the relative abundance of mRNA expression could be explained by several factors. (1) The HSP70 protein concentration is too low to produce detectable immunostaining in Purkinje cells, whereas the in situ hybridization histochemistry is relatively more sensitive. (2) The HSP70 protein is not formed in all of the HSP70 mRNA positive cells, either because of severe injury to these cells or because of a specific translation block. (3) The protein is rapidly degraded posttranslationally and therefore cannot be detected immunocytochemically.

The mechanism by which PCP and other NMDA antagonists damage neurons is unknown. Disinhibition of cortical pyramidal cells with consequent overexcitation has been hypothesized to explain the injury to cingulate and retrosplenial cortex (Olney et al., 1991; Sharp et al., 1994). A similar mechanism could apply to PCP injury to the cerebellum, although clcctrophysiological evidence indicates that systemically administered PCP inhibits rather than excites Purkinje cells in anesthetized rats (Kim and Bickford, 1992).

The possibility that the proposed damage to Purkinje cells is an indirect effect of some systemic response to high dose PCP can not be excluded. However, body temperature measurements indicate that the HSP70 induction and microglial activation is not due to hyperthermia, as PCP (10-50 $\mathrm{mg} / \mathrm{kg}$ ) causes hypothermia (Pechnick and George, 1989; Pechnick et al., 1989, our unpublished observations). Furthermore, the fact that PCP and
MK801 induce almost identical behavioral responses but only PCP affects Purkinje cells, argues against a systemic mechanism.

The indole alkaloid ibogaine induces glial activation and Purkinje cell degeneration in the cerebellum ( $\mathrm{O}^{\prime}$ Hearn and Molliver, 1993; O'Hearn et al., 1993). Interestingly, the distribution of microglial reaction is similar to that shown here, bcing confined to the molecular layer and concentrated in the cerebellar vermis. The chemical structure of ibogaine is similar to harmaline, which produces identical cerebellar toxicity. Like PCP, ibogaine induces psychotomimetic effects and tremor in experimental animals (Zetler et al., 1972; Glick et al., 1991). The mechanism of ibogaine and harmaline neurotoxicity is unclear, although excitotoxic mechanisms mediated by the inferior olive might be involved (O'Hearn and Molliver, 1993). The vulnerability of vermal Purkinje cells to PCP as well as ibogaine and other toxins could be a consequence of regional differences in neural circuitry or of intrinsic cellular vulnerability.

The present study suggests that PCP damages rodent Purkinje cells whereas MK801 does not. Both drugs administered at high doses have indistinguishable behavioral effects, including tremor and ataxia. The absence of evidence of MK801 induced cerebellar damage supports differences in the actions of these agents in the cerebellum. Future studies are required to define the morphology, pharmacology, and mechanism of the proposed Purkinje cell damage by PCP.

\section{References}

Akunne HC, Reid AA, Thurkauf A, Jacobson AE, de Costa BR, Rice KC, Heyes MP, Rothman RB (1991) [ $\left.{ }^{3} \mathrm{H}\right] 1-[1-(2-$ thienyl)cyclohexyl]piperidine labels two high-affinity binding sites in human cortex: further evidence for phencyclidine binding sites associated with the biogenic amine reuptake complex. Synapse 8:289-300.

Akunne HC, Johannessen JN, de Costa BR, Rice KC, Rothman RB (1992) MPTP lesions of the nigrostriatal dopaminergic projection decrease $\left[{ }^{3} \mathrm{H}\right] 1-[1-(2$-thienyl)cyclohexyl]piperidine binding to $\mathrm{PCP}$ site 2: further evidence that PCP site 2 is associated with the biogenic amine uptake complex. Neurochem Res 17:261-264.

Allen HL, Iversen LL (1990) Phencyclidine, dizocilpine, and cerebrocortical neurons. Science 247:221.

Anathan J, Goldberg AL, Voellmy R (1986) Abnormal proteins serve as eukaryotic stress signals and trigger the activation of heat shock genes. Science 232:522-524.

Barbe MF, Tytell M, Gower DJ, Welch WJ (1988) Hyperthermia protects against light damage in the rat retina. Science 241:1817-1820.

Beckmann RP, Mizzen LA, Welch WJ (1990) Interaction of HSP70 with newly synthesized proteins: Implications for protein folding and assembly. Science $248: 850-854$.

Brierley JB, Brown AW (1982) The origin of lipid phagocytes in the central nervous system. I. The intrinsic microglia. J Comp Neurol $211: 397-406$

Brown IR (1990) Induction of heat shock (stress) genes in the mam malian brain by hyperthermia and other traumatic events: a current perspective. J Neurosci Res 27:247-255.

Church J, Lodge D (1990) Anticonvulsant actions of phencyclidine receptor ligands: correlation with $N$-methylaspartate antagonism in vivo. Gen Pharmcol 21:165-170.

Contreras PC, Contreras ML, O'Donohue TL, Lair CC (1988) Biochemical and behavioral effects of sigma and PCP ligands. Synapse 2:240-243.

Dalkara T, Tan E, Erdemli G, Onur R, Zileli T (1990) Electrophysiological evidence for activation of NMDA receptors and its antagonism by MK-801 in cerebral ischemia. Brain Res 532:101-106.

Deshaies RJ, Koch BD, Schenkman R (1988) The role of stress proteins in membrane biogenesis. Trends Biochem Sci 13:384-388.

Domino EF, Luby ED (1981) Abnormal mental states induced by phencyclidine as a model of schizophrenia. In: PCP (Phencyclidine): historical and current perspectives (Domino EF, ed), pp 173-183. Ann Arbor: NPP.

Faingold CL, Randall ME, Naritoku DK, Boersma Anderson CA 
(1993) Noncompetitive and competitive NMDA antagonists exert anticonvulsant effects by actions on different sites within the neuronal network for audiogenic seizures. Exp Neurol 119:198-204.

Finsen BR, Tønder N, Xavier GF, Sørensen JC, Zimmer J (1993) Induction of microglial immunomolecules by anterogradely degenerating mossy fibres in the rat hippocampal formation. J Chem Neuroanat $6: 267-275$.

Fix AS, Horn JW, Wightman KA, Johnson CA, Long GG, Storts RW, Farber N, Wozniak DF, Olney JW (1993) Neuronal vacuolization and necrosis induced by the non-competitive $N$-methyl-D-aspartate (NMDA) antagonist MK-801 (dizocilpine maleate): a light and electron microscopic evaluation of the rat retrosplenial cortex. Exp Neurol 123:204-215.

Frei K, Bodmer S, Schwerdel C, Fontana A (1986) Astrocyte-derived interleukin 3 as a growth factor for microglia cells and peritoneal macrophages. J Immunol 137:3521-3527.

Giulian D, Lachman LB (1985) Interleukin-1 stimulation of astroglial proliferation after brain injury. Science 228:497-499.

Giulian D, Baker TJ, Shih L-CN, Lachman LB (1986) Interleukin-1 of the central nervous system is produced by ameboid microglia. J Exp Med 164:594-604.

Glick SD, Rossman K, Steindorf S, Maisonneuve IM, Carlson JN (1991) Effects and after effects of ibogaine on morphine self-administration in rats. Eur J Pharmacol 195:341-345.

Gonzalez MF, Shiraishi K, Hisanaga K, Sagar SM, Mandabach M, Sharp FR (1989) Heat shock proteins as markers of neural injury. Mol Brain Res 6:93-100.

Gonzalez MF, Lowenstein D, Hisanaga K, Simon RP, Sagar SM, Sharp FR (1991) Induction of heat shock protein 72-like immunoreactivity in the hippocampal formation following transient global ischemia. Brain Res Bull 26:241-250.

Ileroux JA, Tam SW, De Souza EB (1992) Autoradiographic identification and characterization of $s$ receptors in guinea pig brain using $\left[{ }^{3} \mathrm{H}\right] 1$ (cyclopropylmethyl)-4-(2'-(4"'-fluorophenyl)-2'-oxoethyl)piperidine $\left.\left({ }^{3} \mathrm{H}\right] \mathrm{DuP} 734\right)$, a novel $s$ receptor ligand. Brain Res 598:76-86.

Hunt C, Morimoto RI (1985) Conserved features of eukaryotic HSP70genes revealed by comparison to the nucleotide sequence of human HSP70. Proc Natl Acad Sci USA 82:6455-6459.

Jansen KL, Faull RLM (1991) Excitatory amino acids, NMDA and sigma receptors: a role in schizophrenia? Behav Brain Sci 14:34-35.

Jarvis MF, Murphy DE, Williams M (1987) Quantitative autoradiographic localization of NMDA receptors in rat brain using $\left[{ }^{3} \mathrm{H}\right] \mathrm{CPP}$ : comparison with $\left[{ }^{3} \mathrm{H}\right] \mathrm{TCP}$ binding sites. Eur J Pharmacol 141:149152.

Javitt DC, Zukin SR (1991) Recent advances in the phencyclidine model of schizophrenia. Ann J Psychiatry 148:1301-1308.

Johnston RN, Kucey BL (1988) Competitive inhibition of HSP70gene expression causes thermosensitivity. Science 242:1551-1554.

Kim M, Brickford PC (1992) Electrophysiological effects of phencyclidine and sigma agonist ditolylguanidine in the cerebellum of the rat. Neuropharmacology 31:77-83.

Kinouchi H, Sharp FR, Hill MP, Koistinaho J, Sagar SM, Chan PH (1993) Induction of $72 \mathrm{kD}$ heat shock protein and HSP70 InRNA following focal cerebral ischemia an the rat. J Cereb Blood Flow Metab 13:105-115

Lew GM (1989) Changes in norepinephrine concentration following chronic administration of phencyclidine (PCP) to genetically hypertensive and normotensive rats. Gen Pharmacol 20:571-573.

Li Y, Chopp M, Garcia JH, Yoshida Y, Zhang ZG, Levine SR (1992) Distribution of the $72 \mathrm{kD}$ heat shock protein as a function of transient cerebral ischemia in rats. Stroke 23:1292-1298.

Lodge D, Johnson KM (1990) Noncompetitive excitatory amino acid receptor antagonists. Trends Pharmacol Sci 11:81-86.

Longo FM, Wang S, Narasimhan P, Zhang JS, Chen J, Massa SM, Sharp FR (1993) cDNA cloning and expression of stress-inducible rat HSP70 in normal and injured rat brain. J Neurosci Res 36:325-335.

Maragos WF, Penney JB, Young AB (1988) Anatomic correlation of NMDA and ${ }^{3} \mathrm{H}$-TCP-labeled receptors in rat brain. J Neurosci 8:493501

Martinez-Arizala A, Rigamonti DD, Long JB, Kraimer JM, Holaday JW (1990) Effects of NMDA receptor antagonists following spinal ischemia in the rabbit. Exp Neurol 108:232-240.

Massarimi T, Duckles P (1991) Interaction of sigma and phencyclidine receptor ligands with the norepinephrine uptake carrier in both rat brain and rat tail artery. J Pharmacol Exp Ther 256:519-524.

Miller KE, Taese JD, Morrison-Bogorad M (1991) Expression of heat shock protein 70 and heat shock cognate 70 messenger RNAs in rat cortex and cerebellum after heat shock or amphetamine treatment. J Neurochem 56:2060-2071.

Nellgard B, Wieloch T (1992) Cerebral protection by AMPA- and NMDA-receptor antagonists administered after severe insulin-induced hypoglycemia. Exp Brain Res 92:259-266.

O'Hearn E, Molliver ME (1993) Degeneration of Purkinje cclls in parasagittal zones of the cerebellar vermis after treatment with ibogaine or harmaline. Neuroscience 55:303-310.

O'Hearn E, Long DB, Molliver ME (1993) Ibogaine induces glial activation in parasagittal zones of the cerebellum. Neuroreport 4:299_ 302

Olney JW, Labruyere J, Price MT (1989) Pathological changes induced in cerebrocortical neurons by phencyclidine and related drugs. Science 244:1360-1362.

Olney JW, Labruyere J, Wang G, Wizniak DF, Price MT, Sesma MA (1991) NMDA antagonist neurotoxicity: mechanism and prevention. Science 254:1515-1518.

Palma AL, Wang HH (1991) Molecular environment of the phencyclidine binding site in the nicotinic acetylcholine receptor membrane. J Membr Biol 122:143-153.

Pechnick RN, George R (1989) Characterization of the effects of the acute and chronic administration of phencyclidine on body temperature in the rat: lack of evidence for the involvement of opiate receptors. J Pharmacol Exp Ther 248:900-906.

Pechnick RN, Wong CA, George R, Thurkauf A, Jacobson AE, Rice $\mathrm{KC}$ (1989) Comparison of the effects of the acute administration of dexoxadrol, levoxadrol, MK801 and phencyclidine on body temperature in the rat. Neuropharmacology 28:829-835

Pelham HRB (1986) Speculations on the functions of the major heat shock and glucose-regulated proteins. Cell 46:959-961.

Perry VH, Gordon S (1988) Macrophages and microglia in the nervous system. Trends Neurosci 15:273-277.

Quirion R, Chicheportiche R, Contreras PC, Johnson KM, Lodge D, Tum SW, Woods JH, Zukin SR (1987) Classification and nomenclature of phencyclidine and sigma receptor sites. Trends Neurosci 10 444-446.

Reynolds IJ, Miller RJ (1990) Allosteric modulation of $N$-methyl-Daspartate receptors. Adv Pharmacol 21:101-126.

Riabowol KT, Mizzen LA, Welch WJ (1988) Heat shock is lethal to fibroblasts microinjected with antibodies against hsp70. Science 242 : 433-436.

Rothman RB, Audrey AA, Monn JA, Jacobson AE, Rice KC (1990) The psychotomimetic drug phencyclidine labels two high affinity binding sites in guinea pig brain: evidence for $N$-methyl-D-aspartate coupled and dopamine reuptake carrier-associated plencyclidine binding sites. Mol Pharmacol 36:887-896.

Rothman RB, Reid AA, Silverthorn M, de Costa BR, Monn JA, Thurkauf A, Jacobson AE, Rice KC, Rogawski MA (1992) Structure activity studies on the interaction of biogenic amine reuptake inhibitors and potassium channel blockers with MK-801 sensitive (PCP site 1) and insensitive (PCP site 2) $\left[{ }^{3} \mathrm{H}\right] \mathrm{TCP}$ binding sites in guinea pig brain. In: Multiple sigma and PCP receptor ligands: Mechanism for neuromodulation and neuroprotection (Kamanka J-M, Domino EF, eds), pp 137-146. Ann Arbor: NPP.

Seiler N, Grauffel C (1992) Antagonism of phencyclidine-induced hyperactivity in mice by elevated brain GABA concentrations. Pharmacol Biochem Behav 41:603-606.

Sharp FR, Lowenstein D, Simon RP, Hisanaga K (1991a) Heat shock protein HSP70 induction in cortical and striatal astrocytes and neurons following infarction. J Cereb Blood Flow Metab 11:621-627.

Sharp FR, Jasper P, Hall J, Noble L, Sagar SM (1991b) MK-801 and ketamine induce heat shock protein HSP72 in injured neurons in posterior cingulate and retrosplenial cortex. Ann Neurol 30:801-809.

Sharp FR, Butman M, Wang S, Koistinaho J, Graham SH, Sagar SM, Noble L, Berger P, Longo FM (1992) Haloperidol prevents induction of the HSP70 heat shock gene in neurons injured by phencyclidine (PCP), MK801, and ketamine. J Neurosci Res 33:605-616.

Sharp FR, Butman M, Koistinaho J, Aardalen K, Näkki R, Massa SM, Swanson RA, Sagar SM (1994) Phencyclidine induction of the IISP70 stress gene in injured neurons is mediated via multiple receptors and voltage gated calcium channels. Neuroscience, in press. 
Simon RP, Cho H, Gwinn R, Lowenstein DH (1991) The temporal profile of $72-\mathrm{kDa}$ heat shock protein expression following global ischemia. J Neurosci 11:881-889.

Streit WJ, Kreutzberg GW (1987) Lectin binding by resting and reactive microglia. J Neurocytol 16:249-260.

Streit WJ, Graeber MB, Kreutzberg GW (1988) Functional plasticity of microglia: a review. Glia 1:301-307.

Su T-P (1993) Delineating biochemical and functional properties of sigma receptors: emerging concepts. Crit Rev Neurobiol 7:187-203.

Thomas WE (1992) Brain macrophages: evaluation of microglia and their functions. Brain Res Rev 17:61-74.

Tytell M, Barbe MF, Gower DJ (1989) Photoreceptor protection from light damage by hyperthermia. In: Inherited and environmentally induced retinal degenerations (LaVail ML, ed), pp 523-538. New York: Liss.

Vass K, Welch WJ, Nowak TS Jr (1988) Localization of $70 \mathrm{kD}$ stress protein induction in gerbil brain after ischemia. Acta Neuropathol (Berl) 77:128-135.
Vass K, Berger ML, Nowak TS Jr, Welch WJ, Lassmann H (1989) Induction of stress protein HSP70 in nerve cells after status epilepticus in the rat. Neurosci Lett 100:259-264.

Walsh DA, Klein NW, Hightower IE, Edwards MJ (1987) Heat shock and thermotolerance during early rat embryo development. Teratology 36:181-191.

Walsh DA, Li K, Speirs J, Crowther CE, Edwards MJ (1989) Regulation of the inducible heat-shock 71 genes in early neural development of cultured rat embryos. Teratology 40:321-334.

Welch WJ, Sulhan JP (1986) Cellular and biochemical events in mannmalian cells during and after recovery from physiological stress. $\mathbf{J}$ Cell Biol 103:2035-2052.

Wong EHF, Kemp JA, Priestley T, Knight AR, Woodruff GN, Iversen LL (1986) The anticonvulsant MK-801 is a potent $N$-methyl-D-aspartate antagonist. Proc Natl Acad Sci USA 83:7104-7108.

Zetler G, Singbartl G, Schlosser L (1972) Cerebral pharmacokinetics of tremor-producing harmala and iboga alkaloids. Pharmacology $7: 237-248$. 